\title{
高静圧下におけるガラス板の打拻き加工*
}

\author{
山口勝 美**, 五十君 清司*** \\ 社 本 英 二十, 小嶋純 - ${ }^{+}$
}

\section{Piercing Sheet Glass under High Pressure}

\author{
Katsumi YAMAGUCHI, Kiyoshi ISOGIMI, \\ Eiji SHAMOTO, and Junichi KOJIMA
}

\begin{abstract}
Many kinds of recently developed materials are very hard and brittle and it is very difficult and expensive to process these materials. So it is necessary to develop an easier and more economical method to process these materials. As an example, punching holes in sheet glass was studied in this paper. Because punching holes in sheet glass by ordinary methods is impossible, this paper presents a method for punching holes in sheet glass under statical high pressure. This research confirmed that it is possible to punch holes in sheet glass, and clarified the conditions needed to obtain good holes without defects.
\end{abstract} Key Words: Manufacturing Technology, Piercing, Punching, Hydrostatic High Pressure, Glass
Sheet, Brittleness

\section{1. 緒匐}

近年，セラミックスなどの高硬度，高ぜい性材料の 開発が進み，その加工法が問題となっている. 現在, これらの材料はダイヤモンド研削や超音波加工などに よって加工されることが多いが, これらの加工法は能 率が琹くコストが高いものとなっている。もしこれら の村料に量産加工法が開発されれば，加工能率向上， 加エコスト低下に貢献でき，材料の利用範囲を広げる ことができるだるう。

本研究は，これらの高ぜい性材料に対して量釐可能 な加工法を開発するための第 1 段階として，代表的ぜ い性材料であるガラスの冷間打抜き加工を試みたもの で，打抜き加工のための装㨁を試作し，打抜き可能な 条件を明らかにしたものである。

\section{2. 実 験 装 置}

\section{$2 \cdot 1$ 加工原理 一般に，ぜい性材料の破壊は材}

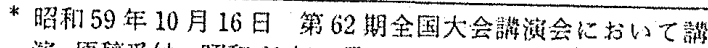

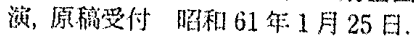

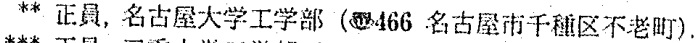

*** 正员，三1

†学生温, 名古星大学大学院。

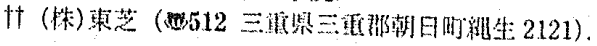

料内部の久陥やき裂の先端で局所的に生ずる応力集中 によって起こるため, マクロな応力はかなり低い值で 材料は破壤する，したがって，ぜい性材料を通常の打 抜き方法で打ち抜こうとすると，打报きに要する力に よって，破㙏しては困る場所で局部的応力が破壊を引 き起こし材料の打抜き穴以外のところにクラックが生 じたり破铱したりしてしまう。

そこで，ぜい性材料を打ち抜くためには，打抜き部 分以外の材料内にあらかじめ圧縮応力場をつくり，打 抜き時に生じる引張り応力に対抗させ，打抜き部分以 外の破壊を扔さえる方法が洘えられる。本研学の笑験 装置は、この上うな原理から設計されたものである。

$2 \cdot 2$ 打抜き装置の棈造 打抜き装置の全体図を 図1に示し，その機構図を図 2 に示す。

図2で(1)がポンチ，(2)がダイスである。打拻きは，ま ず加性(4)，(7)で打ち拡こうとするがラス板を上下か ら極めて高い圧力で加圧してから行う。この装置にお けるポンチの打抜き運動は，ボルト(3)に取付けたナッ ト(6)を回転させることによりブッシング(5)橫方问に すべらせ,ブッシングのデーパ部を介してポンチ(1)

下方向に押すことで行わせる。

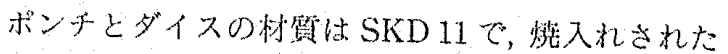

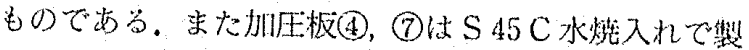


作した。

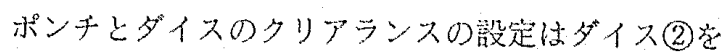
穴径の翼应ものに取り変えることにより行った。

この装㯰は図1に示す上うにすべてダイスせットに 組认込まれ，ダイスセットごとプレスで加压される。

な招ポンチを一定速度で送り込むために，ナット(6) の締め付けはモー夕駆動により行った。本实涗でのボ

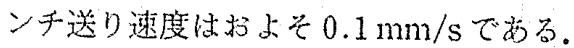

$2 \cdot 3$ 打掖き装置の検出機模打报き過程它調べ るためには，加工中の材料の変形やポンチにかかる荷 重の経過を把握することが重要で占る。そこで，犾ン チにかかる荷重とポンチストロークとを同時に検出し

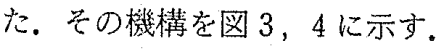

ポンチ荷重の湘定は図 3 に示すようにポンチの一部 を切欠き，その网柱の中央にプラス形のひずみダージ でホイートストンブリッジを形成させ，ひずみ計の温 度補債をすると同時にポンチに加わる偏心荷重による 曲げモーメントの影響を相殺させて，行った。

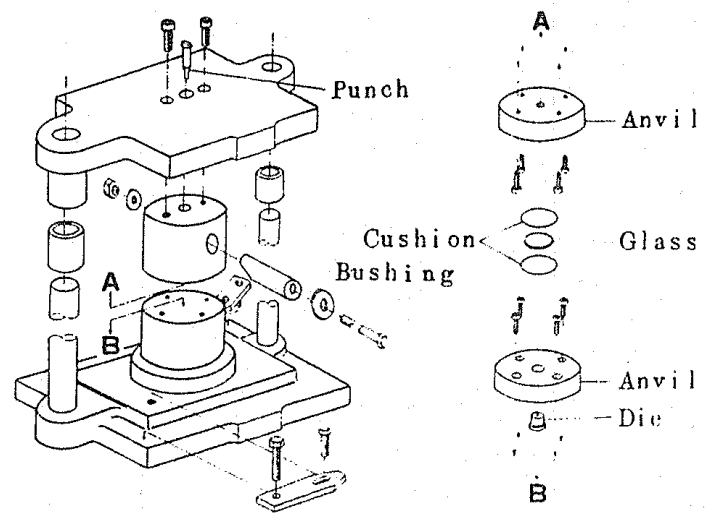

図 1 打抜装置全体図

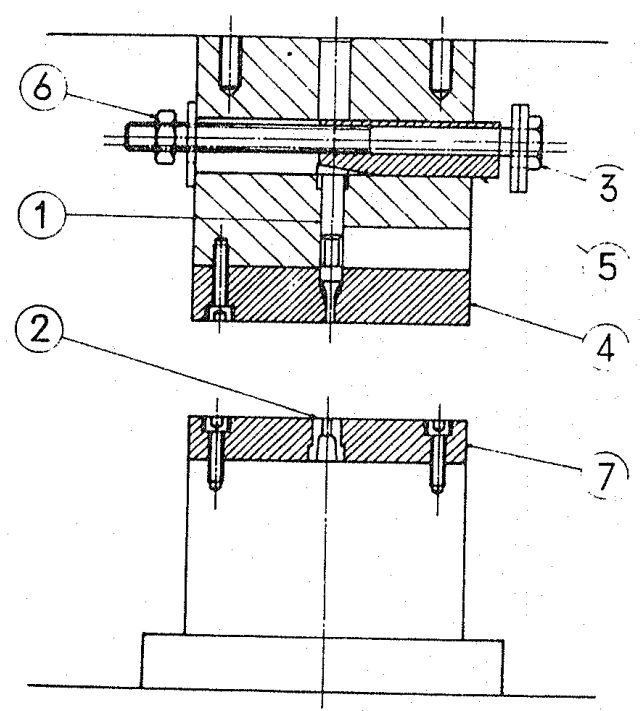

図 2 打抜き装置機構図
ポンチストロークの検出は，図40ように板ばねの

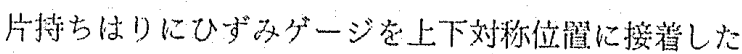

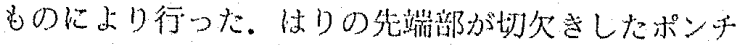

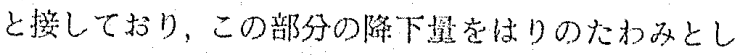
てひずみダージによって検出し，ポンチストロークを 求めた。

なおこ机らの検出機棰については，それてれについ て検定試崕を行い，奏用上十纷な線形性と再現性を得 た.

\section{3. 紘 衝材}

2 章で述べたように，本実験ではガラス板を圧縮し た状態で打抜き加工を行うのであるが，加圧板で直接 ガラス板を㴼すると，図５に示すようにガラス全体 が粉砕してしまいやすい。

これは，加压板とガラス板の両方に微小なうねりや 表面の凹凸があることや，上下の加圧板の平行度が完 全でないことも原因の一つと考えられる。

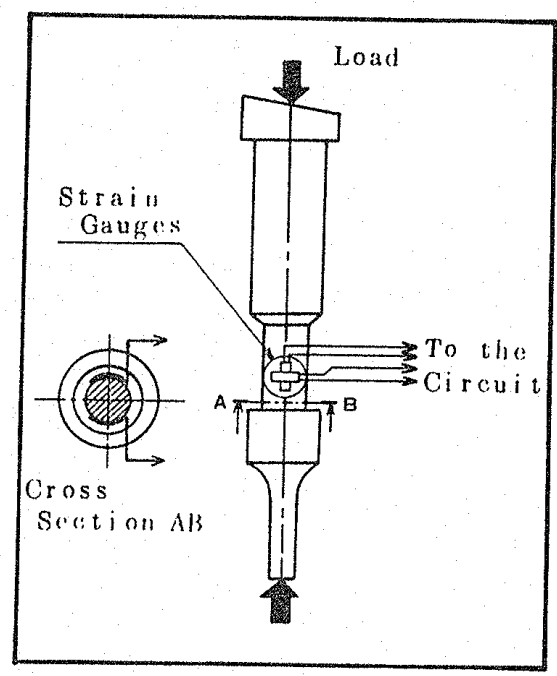

図 3 ポンチ荷重検出部

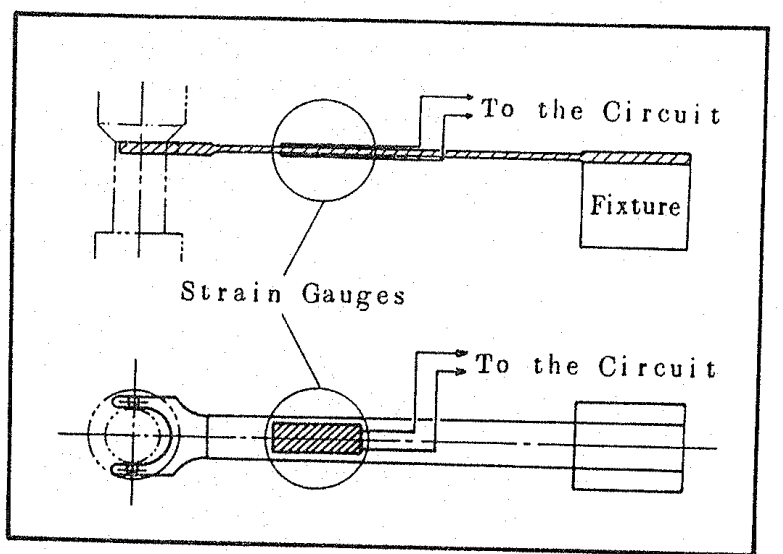

図 4 ポンチストローク検出部 
そこで本研究では，ガラス板と加圧板との間に軟質 の薄板（緩衝材と名付ける）をはさむことを試みた。 以下に，最適な緩衝材を選ぶために行った予備実験に ついて述べる。

実験装置は 2 章で紹介した装置をそのまま使用し た。加圧板は平面研削により表面粗さ $R_{\text {max }}=3 \mu \mathrm{m}$ 以 下に仕上げた。

本研究に使用したがラス板はすべて，市販透明普通 板ガラスでありその表面粗さは $R_{\max }=1 \mu \mathrm{m}$ 以下であ る.この緩衝材の実験では，ガラス板の形状はすべて 直径 $45 \mathrm{~mm}$ の円形とし, 板厚は $0.7 \mathrm{~mm}$ のものを使 用した。

以上の実験条件で，各緩衝材について得られた結果 を図6に示す。

図 6 の縦軸は所定の圧力を加えた時に粉砕せずに残 るガラス板の面積の割合 (残余率) を表している。図 6 より，本実験で扱った緩衝材の中では $0.05 \mathrm{~mm}$ 厚 の銅はくが最もよく，最高圧力 $1000 \mathrm{MPa} て ゙ も 80 \%$ 以上の残余率を示した。また，緩衝材を使用せず加止 板で直接ガラスを加圧する場合恃，圧力 $400 \mathrm{MPa}$ ま ではガラス板はほとんど粉砕しないがそれを超えると 全面が粉砕してしまい原形をとどめない。

同じ材質の緩衙材では，薄いもののほうが残余率が 良かった。これは，厚いものでは圧縮応力によって変 形が起こり半径方向に広がりやすいためで，ガラスに 加わるはずの半径方向の拘束力が相刘的に減少するた めと思われる。

\section{4. 打抜き实験}

$4 \cdot 1$ 実験条件 3 章で述べた予備䇛験の結果よ り，以後の笑験では緩衙材として $0.05 \mathrm{~mm}$ 厚の銅は くを使用した。

試料ガラスは，すべて同じ市販透明普通板ガラスを

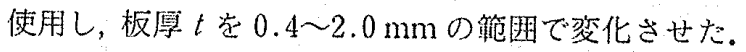
ガラス板の形状は，直径 $45 \mathrm{~mm}$ の内形と，一辺 50

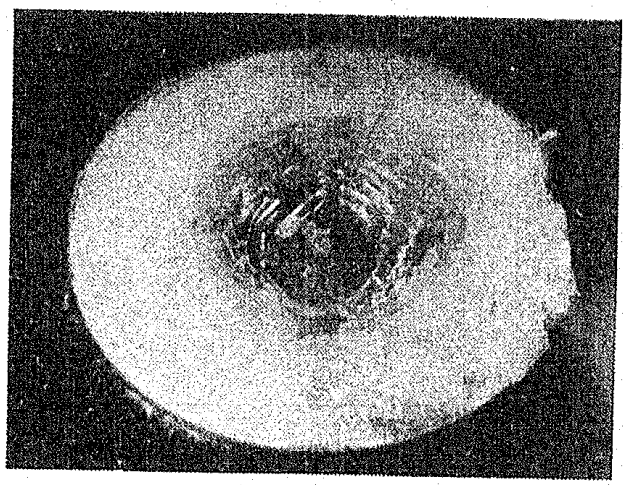

图 5 ガラス板粉确例 $\mathrm{mm}$ の正方形の二つを用いた。

ポンチ直径 $d$ は $3 \mathrm{~mm}$ で一定とし，ダイス穴径 $d^{\prime}$ を3.05〜9.00 $\mathrm{mm}$ の範囲で変化ざることによりク リアランス $c$ を変化させた。

な抢実駼条件を変えるパラメータは図 7 を参照し $\tau$

(1) ガラス板を圧縮する圧力 $P$

(2) 相対クリアランス $c / t$

(3) 相対ポンチ直径 $d / t$

の三つを主なパラメータとし，これらの条件がいかな る条件を满たす時，ぜい性材料であるガラスを打ち抜 くことができるかを調べた。

4 -2 打抜き穴の形成 本装置による打抜き穴の 例を図 8 に示す。

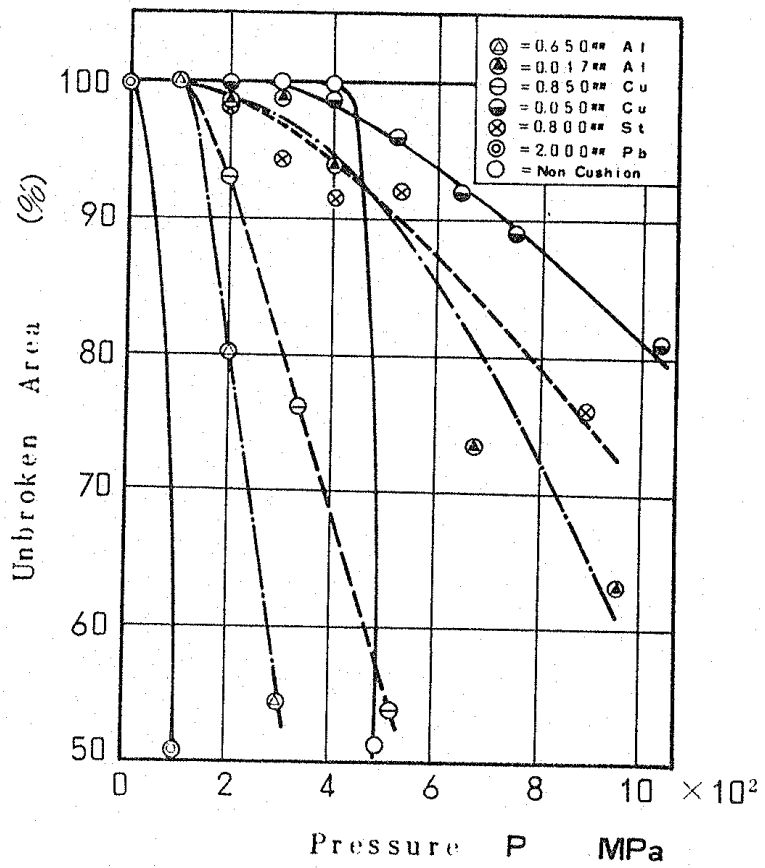

図 6 各種䌊街材によるガラス板の残余率

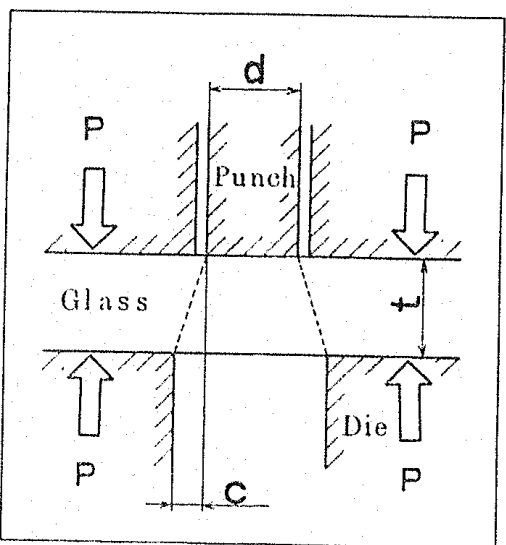

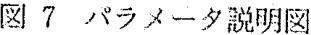




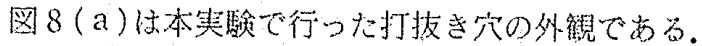

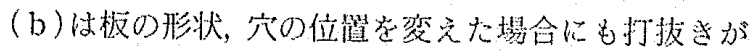
可能であることを示すための例で斿为。

また本实験では，加工中のガラスの学動学知るため にホポチストローグ梌中で停止して打拢き途中の ガラス断面観察した。ちの写其图 9 に示す。ここ で( いる。

図 9 よりこの場合には，打抜き穴はまずポンチ側か ら最初のクラックが入り，导の後内部に無数のクラッ クが入って穴が形成されている。また图 9 (c) を見る とクラックは途中で止まり加圧域には伸展せず穴があ いていることがわかる。

\section{5. 打拔き抵抗}

加工中にポンチにかかる荷重がポンチストロークに 沁じて翂化する様子を求めた例を図 10，11 に示す。こ こで糡軸は，ポンチにかかる荷重を打抜き円筒面の面 積で割った值（この値は応力の次元をもつが事実上ポ ンチ荷重の変化を示すので, 以後ポンチ荷重と呼ぶ) を用いた。図 10 は圧力 $P$ を変化させた時の線図の例 であり，図11は相対クリアランス $c / t$ を变化させた

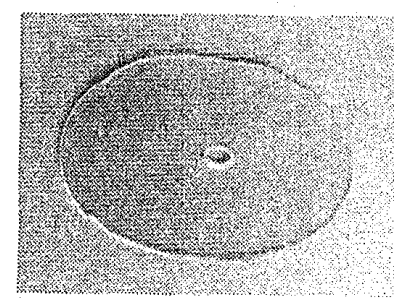

(a)

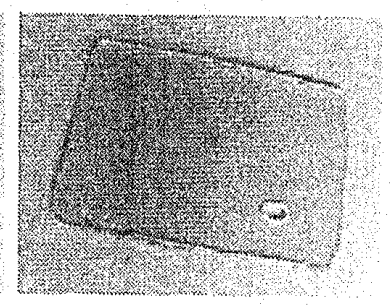

(b)

図 8 打报き穴外観

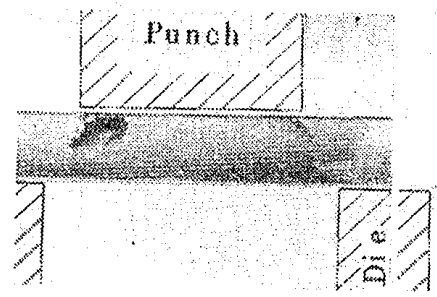

(a)

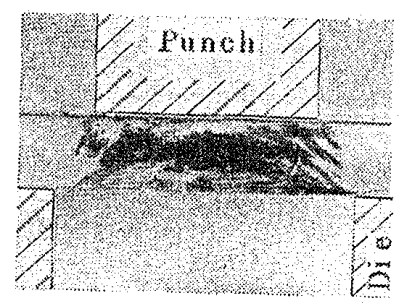

(c)

図 9 打拔き途中のガラス断面
時の線图の例である。

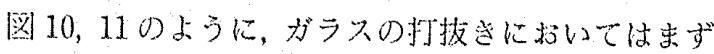

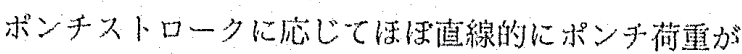

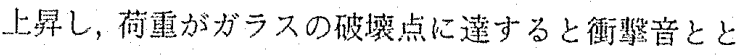

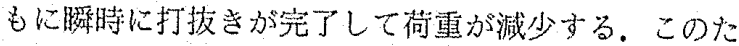

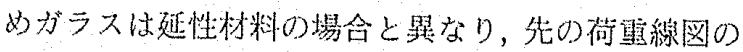
ように罗高点に扔いて銠くとがった線图となる。

これらの線図で, ポンチ荷重の最大值をガラスの打 拔き抵抗とし，この値と圧力Pならびに相対クリア

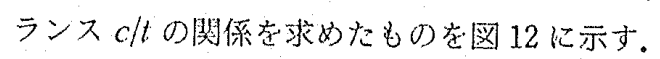

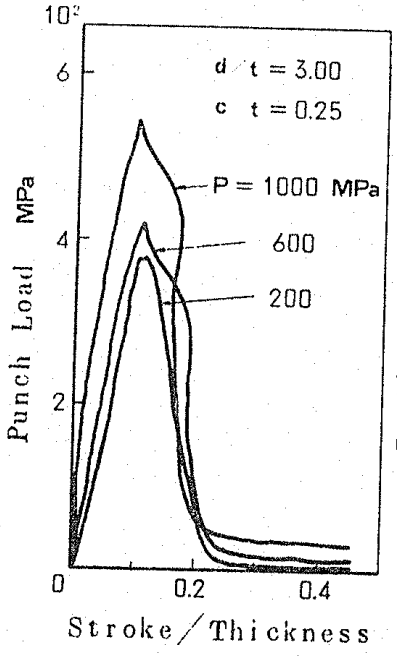

図 10 圧力 $P$ 変化による 荷重線図

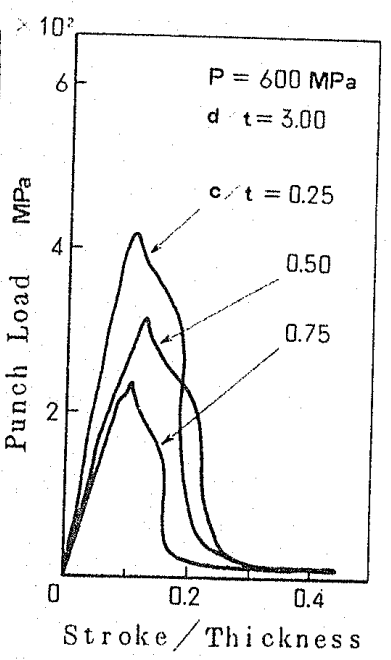
荷重線図
図 $11 \mathrm{c} / \mathrm{t}$ 変化による

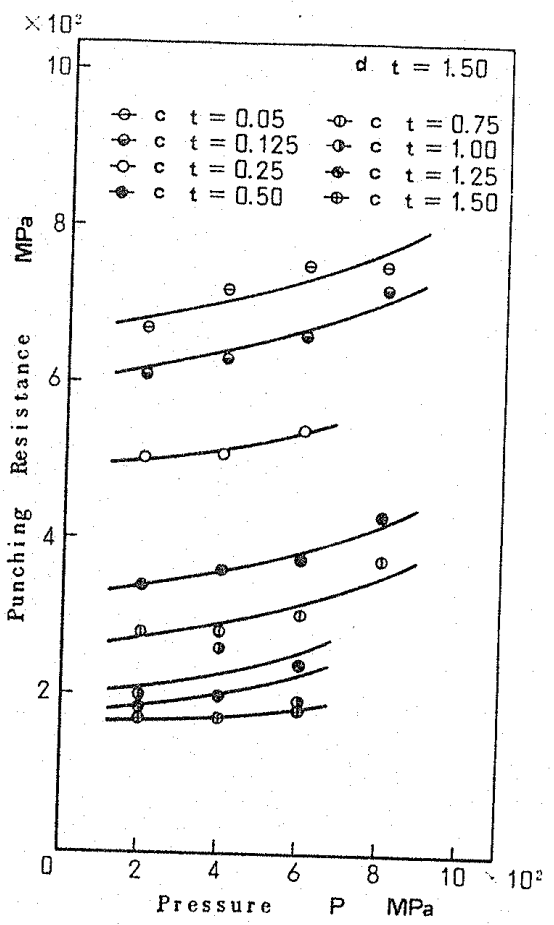

図 12 打抜き抵抗と圧力 $P$ の関係 
図 12 より，相対クリアランスが大きいほど，また圧 力 $P$ が低いほど打拉き抵抗は小さくなることがわか る. 相対クリアランスが大きいほど打抜き抵抗が小さ くなるのは, 相対クリアランスが小さい時に比べて同 じポンチ荷重でも板断面に大きな曲げモーメントが生 じ，そのため大きな引張り応力が生じてクラックが発 生しやすくなるためと考えられる。また圧力 $P$ が低い ほど打抜き抵抗が小さくなるのは, ガラス内の圧縮応 力が低くそれに対抗してクラックを発生させるのが容 易であるためと考えられる。

打抜き加工においては，打抜き抵抗が低いことが望 ましいが，この目的を満たすためには，上述のように 相対クリアランスを大きくし圧力Pを低くすること になる.しかし相対クリアランスを大きくすれば, 打 抜き穴の精度を下げる原因となりやすく，また圧力 $P$ を低くするほど，当然打挍き部分以外にクラックが発 生する危険が大きくなる。このため良好な打抜き穴を 得るためには，必然的にある程度きびしい条件下で打 抜き加工を行わなければならない。

\section{6. 打抜き穴の評価}

打抜き穴の性状は，打抜き条件によっていろいろ異 なったものとなる。その代表的なものを図 13 に示す. すなわち条件によって，ほぼテーパ状の破断面だけ のもの(a), 円周方向クラックの入るもの(b), 半径 方向に微小クラックの入るもの $(c)$, 半径方向に大き なクラックの入るもの(d)などに分けられる。

これらの板穴の性状を評価するために，次のような 基準を考えた。 まず図 14 で，ガラスに損第の見られる

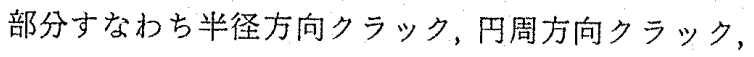
破断面のうちで，最大なものの先端から他方の先端ま での距離を最大寸法 $D_{\text {max }}$ とする。この值が小さいほ ど損算が小さくてよい.この最大寸法 $D_{\text {max }}$ を相対的 に評価するために相刘損傷長さ $L=\left(D_{\max }-d\right) / 2 t$ を 定義し，これを評価の基準とした，評価は 4 段階に分 類し，以下のように定めた。

(1) 評洒 $\bigcirc$ : 図 13(a)に示すように, 半径方向 クラックが全くなく、円周方向クラックはほとんど認 められないもので，ほぼーパ状の破断面だけででき ているもの。相対損傷長さは $L<10$ 籍围に入る。

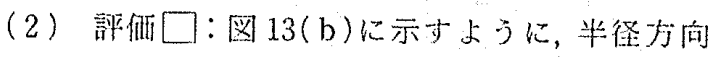
クラックがないもの，刚周方向クラックはあまり大さ くなく，相対損鹪長さは， $1 \leqq L<20$ 範畔に入るも 0.

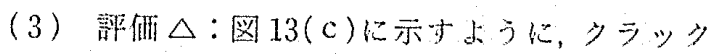

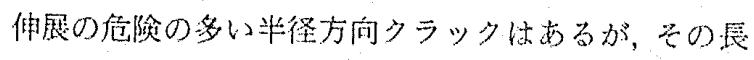

さは短いもの，通常，円周方向クラックを伴っており， 相対損傷長さは， $1 \leqq L<2$ の範囲に入る。

(4) 評価 $\times$ : 図 13(d)に示すように, 大きな半 径方向クラックがあるか, または大きな円周方向クラ

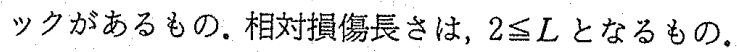
破壤してしまったものはこの評価に入る。

\section{7. 打抜き加工条件}

本実験で変化させた種々の条件のうちで，いかなる 条件の組合せのとき良好な打抜き穴が得られるかを示 したものが図 15 である。図 15 で良好な打抜き穴を得 ることができたのは，○で示された領域である。

図 15 より，良好な打抜き穴を得るには，圧力 $P$ は 高く，相対クリアランス c/t は 0.3〜0.7の範囲にお さえなければならない。相対クリアランスが小さいと 円周方向クラックや半径方向クラックが発生しやす い。他方相対クリアランスが大きすぎると，穴に大き なテーパがついて評価が下がる。

相対ポンチ直佳 $d / t$ に関しては，これが小さいほど

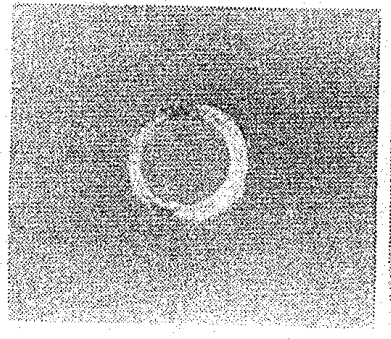

(a)

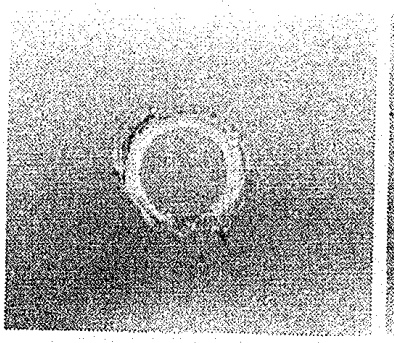

(c)

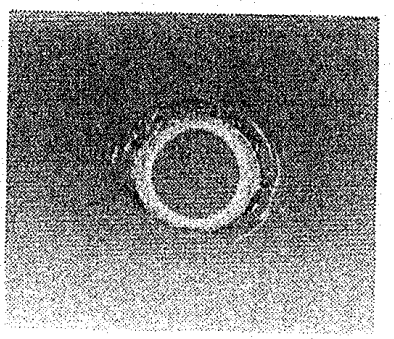

(b)

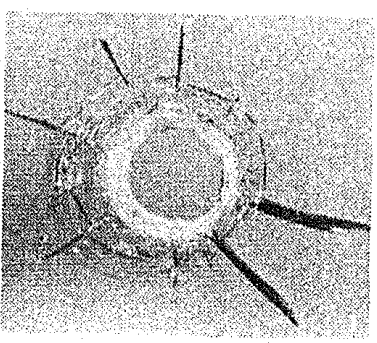

(d)
図 13 打技き分の代婊例

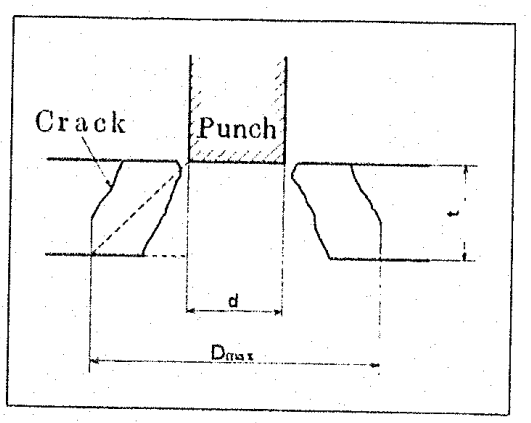

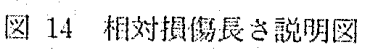



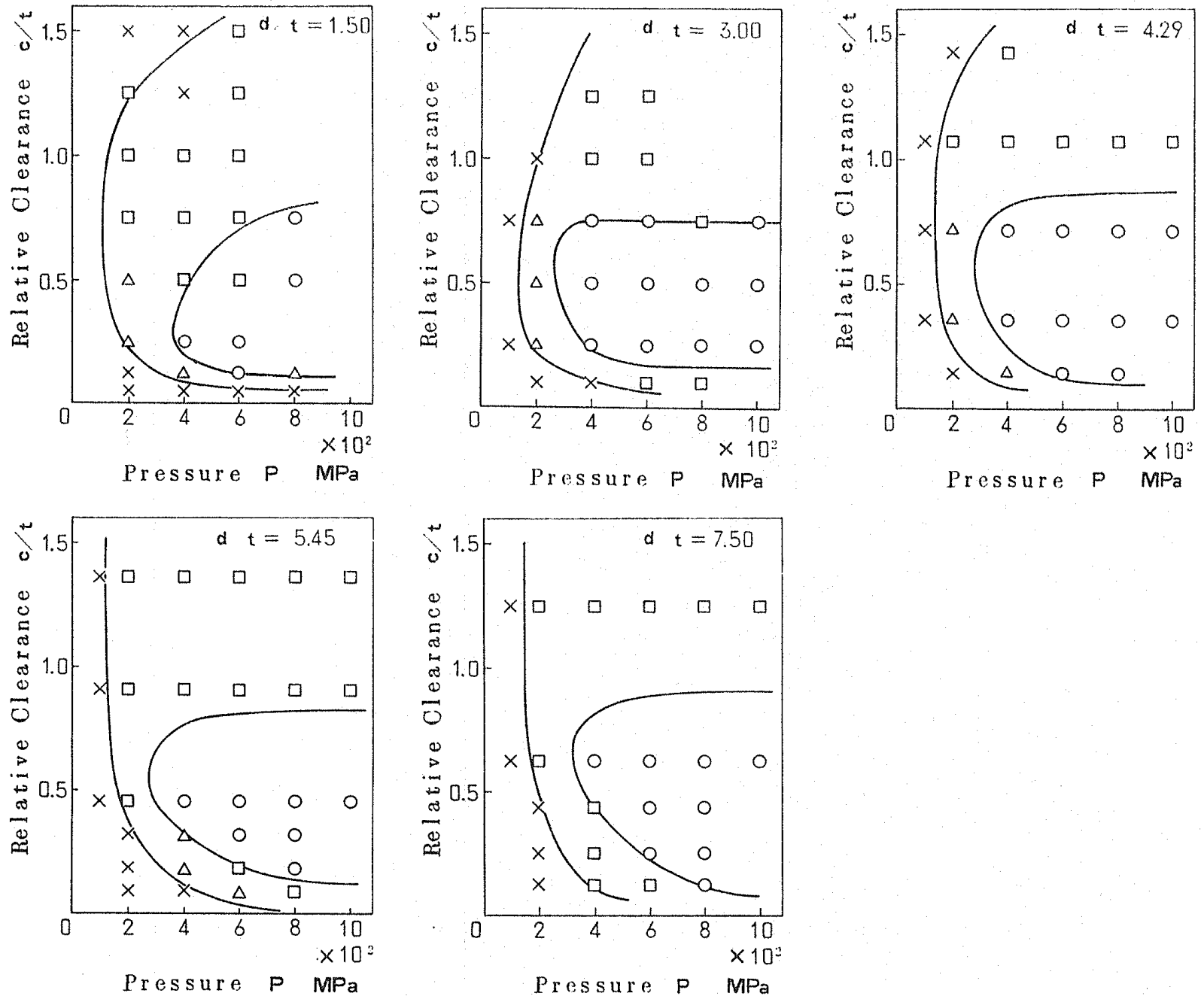

Pressure $\mathrm{P}$ MPa

図 15 打抜き加工可能条件

深穴を打ち掖くことになり，加工が困難になると考え られる。図 15 を見ると， $d / t=1.50$ の条件では○の領 域が狭くなっており，このことから， $d / t=2$ を超える と穴加工が難しくなることが予想される。

結局，ガラス板に対する精度よい打抜き穴加工は, 圧力 $P$ が $400 \mathrm{MPa}$ 程度以上で, 相対クリアランスが $0.3 \sim 0.7$ 範囲においてのみ可能であること, 圧力 $P$ が大きすぎるとガラス板の周辺部に欠楩が生じる 問題のあること，相対ポンチ直径が 2 付近を下まわる
と急激に打抜き可能条件が狭められること，がわかっ た。

\section{8. 結言}

本実験で用いた条件により，ぜい性材料であるガラ スを打ち抜くことが可能であることが示された。そし て良好な打抜き穴を得る条件を明らかにすることがで きた。

\section{討}

〔買問〕

神篤、敬

\section{〔東京工業大学精密工学研究所〕}

高静圧を加えて打抜き加工を行う実験装置を與味深 く择見した、以下の点についてご見解をうかがいたい.

（1）紙数の関係と思うが, 佐藤ら(付1)(付3)によ
ってぜい性材料の側圧による切断が公表されているの を引用していないのは残念である。

（2）打ち拔かれたがラス片が粉砕されて使用でき ないが，これについても，熱応力(付2)(付3)によるがラ スの切断が発表されて奏用されているのに引用がな 
(1).

（3）打抜きという表現は慣用と異なると思う。

(回答（1)，（2）ぜい性材料の加工という意昧 ではご指摘の文献を引用するのが適当であったかと思 う.また，ガラスの加工という意味では多くの文献が あろうかと思う。ご指摘の文献は，側圧，熱応力を利用 しクラックを発生させそれを加工に利用するのに対 し，著者の方法は，高い静水圧をもって打抜きの際生 ずるクラックの発生，伝ぱを防ぐのが目的の手法であ る.その意味では通常の打抜きの文献のほうが近いも のが多くあってこれを取り上げる必要があり膨大な文 献になる。紙面の都合と本手法に狭く限った結果ご指 摘の文献をあえて取り上げなかったことをご了承いた だきたい。

（3）本手法は打ち抜かれた穴側はくずとなるが， 穴側も製品として利用できる方法も現在調べており， 成功例もある。一応気持ちのうえでは打拔きという表 現をしている。

〔質問〕宮川松 男〔長网技術科学大学〕

実用に供しうるデー夕を提供していることに敬意を 表す.
討論にならないとは思うが，この種の研究に文献が 全く引用されていないので, 気のついたことを二, 三 お知らせしておきたいと思う。

ガラスの高静水圧利用による切断については，佐藤 教授 (元東京工羍大学, 現日本大学工学部) らの研究発 表が本会でもあり，また，東洋ガラス(株)からの特許 も出ていて，一部実用段階にある。

また，金属の高静水圧下のせん断挙動については， 篠原 (東京都立大学) ほかの研究が本会で公表され，金 属アモルファス材料のせん断加工については，中川ほ か（東京大学生主技術研究所）の研究已ある。

これらは，著者らの研究の基礎的データの考察に欠 かせないものと思うので，ぜひ，参考にしていただき たい.

〔回答〕神馬氏への回答 $(1),(2)$ と同様であ る。なお，本手法は高静水圧下のガラスのせん断挙動 を検討するところまで達していない，打抜きの可能性 を示したものとご了解いただきたい.

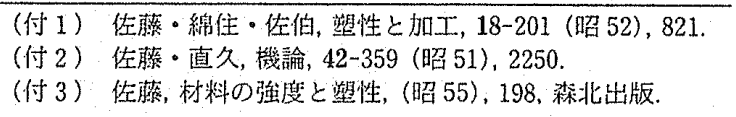

